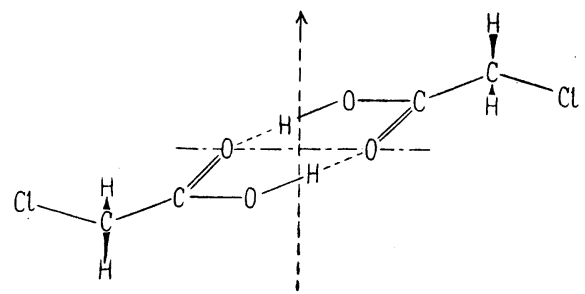

図 5 モノクロル䣷酸 $\beta$ 形の分子配列模形

線はわずかな波数差で平行スペクトル線と直角スペクトル線とが 異なることである。

吸収の異方性から検討すると $\mathrm{OH}$ 面内变角, $\mathrm{OH}$ 面外变角振 動が同時に平行, 直角両成分をもつためには，2 個のカルボキシ ル基面が相互に傾きをもつ polymer 形，または dimer 形で分 子面が結晶の伸長方向および 水平軸に対し齐 $45^{\circ}$ に近い傾きを もつ場合が考兄らる。

溶液の赤外線吸収スペクトルとの比較において $\alpha$ 形は無極性溶 液のスペクトルとかなり異なるスペクトルを与えており, 後者は 考えにくく, かつ $\beta$ 形は乳鉢中で摩擦する場合 $\alpha$ 形に移行するこ とから $\beta$ 形， $\alpha$ 形における分子配列の近いことを考虑する必要が ある。

$\beta$ 形の模形，図 5 の右左のカルボン酸の分子軸のまわりの回転 により水素結合㥞式を dimer 形から endless helix 形へと変 化すると考えると図 6 のような模形が推論され，吸収の異方性の 説明もつく。

なお平行成分と垂直成分の $\mathrm{OH}$ 面内変角振動は endless helix の対の片側のカルボン酸と相手側のカルボン酸の同位相的変角振 動と逆位相的变角振動が観測されるのであろう。

正確な分子配列の検討には $\alpha$ 形， $\beta$ 形それぞれ結晶解析を行な

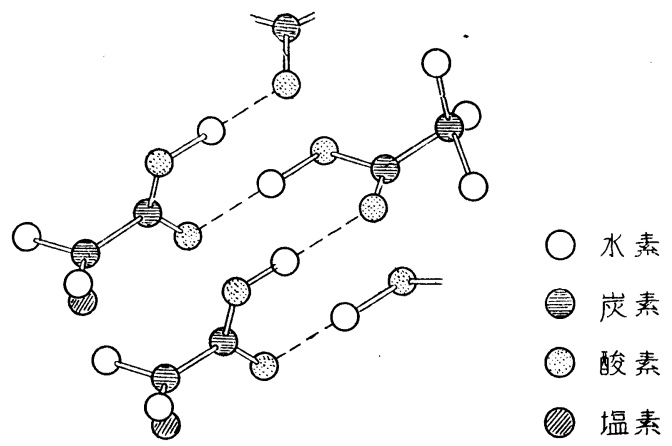

図 6 モノクロル酢酸 $\alpha$ 形の分子配列模形
う必要がある。

\section{5 総括}

1. $\beta$ 形は $\mathrm{C}-\mathrm{Cl}$ 伸縮振動, $\mathrm{CCO}$ 变角振動, $\mathrm{CH}_{2}$ 縦ゆれ振動 等に扔いて 2 本に分枝しているが， $\alpha, \gamma$ 形のスペクトル線の合 成とはみられず, 混晶の可能性はない。

2. $\alpha, \beta, \gamma 3$ 形は $\mathrm{OH}$ 面外变角, $\mathrm{CCO}$ 変角振動に差がみら れるが，C-C 伸縮振動， $\mathrm{CH}_{2}$ に関する変角振動に大きな差がみ られず, 内部回転の差による多形とは認め㤎たい。いずれも $\mathrm{C}-\mathrm{Cl}$ 軸とカルボキシル基面が同一面にある分子形で分子配列を異にす る多形と推論される。

3. $\beta, \gamma$ 形忹無極性溶液スペクトルに非常に 類似したスペク トルを与光, 偏光赤外線吸収の異方性からも $\beta$ 形は dimer 形, またはこれに近い構造が推論される。なおラマン，赤外のスペク トル線の交互禁制は成立しないが，結晶場の対称の低いためか, あるいは dimer 形よりわずかにはずれた構造をとるかは結晶解 析から決定する必要がある。

4. 水素結合の endless helix 構造をとるカルボン酸としては ギ酸17)および酶酸18)があるが,著者はそれぞれの固態およびO重水素化合物の固態のスペクトル測定を行なったが, とくにOH, OD 面外変角振動に着目すると，一般の dimer 形カルボン酸と 大差はみられず，多少低波数に出現する傾向がみられ，モノクロ ル䣷酸の $\alpha$ 形の $\mathrm{OH}(\mathrm{OD})$ 面外変角振動の低波数へのシフトと対 比しうる。

$\begin{array}{ccc} & \begin{array}{c}\mathrm{OH} \text { 面外変角振動 } \\ \left(\mathrm{cm}^{-1}\right)\end{array} & \begin{array}{c}\text { OD 面外変角振動 } \\ \left(\mathrm{cm}^{-1}\right)\end{array} \\ \text { ギ酸 (固態) } & 936 & 662 \\ \text { 酢酸 (固態) } & 888 & 670\end{array}$

以上の結果からモノクロル酢酸の $\beta, \gamma$ 形は dimeric 形または これに近い構造をとり， $\alpha$ 形は分子間水素結合の endless helix 構造の polymeric 形と推論した。

本研究の一部は東京大学理学部化学教室水島研究室に扣いてな されたもので，終始愁篤な御指導を賜わった水島三一郎教授，島 内武彦助教授，市鴆 勲助教授はじめ御助言をいただいた宮沢辰 雄博士，中川一朗博士に厚く感謝申しあげる。また研究ならびに 発表の機会を与えられた大日本製薬株式会社学術部長加藤貞武博 士，同研究部長筒井 清博士，同研究部課長於勢真輔博士に厚く 感謝の意を表する。

（昭和 32 年 10 月，構造化学討論会（一部）発表）

17) F. Holtzberg, B. Post, I. Fankuchen, Acta. Cryst. 6, 127 (1953). 18) R. E. Jones, D. H. Templeton, ibid. 11, 484 (1958).

\title{
2-ピリドンおよび 4-ピリドンの赤外線吸収スペクトル
}

(昭 和 33 年 7 月 14 日受理)

中 村 清†

2-ピリドン (2-オキシピリジン) 扣よび 4-ピリドン (4-オキシピリジン) の分子構造については多くの研究が行なわれて扣り， 固態打よび溶液に打いていずれもケト形構造を推定している。しかし気態に打ける測定は行なわれていないので，著者は気態の赤 
外線吸収スペクトルの測定を行ない,ヶト形構造をとるととを推論した。また液態扣よび固態のスペクトルを測定したが，固態にお いて 2-ピリドン，4-ピリドンともに高融点形抽よび低融点形の 2 形の存在するととをみいだし，いずれも $\mathrm{C}=\mathrm{O}$ 伸縮， $\mathrm{N}-\mathrm{H}$ 伸縮 振動に帰属すべきスペクトル線を有し，分子配列を異にするケト形構造の多形であるととを認めた。つぎに重水素化および偏光赤 外線吸収の異方性の測定結果から，主として NH 変角振動の緭属を行った。2-ピリドン，4-ピリドンに打ける $\mathrm{NH}$ 面内変角振動 は一般の值より高波数の $1550 \sim 1610 \mathrm{~cm}^{-1}$ とみられる点特長がある。

\section{1 緒言}

2-ピリドン，4-ピリドンはアルキル化に際し，アルキル基の種 類および反応条件によって $O$-アルキル誘導体あるいは $N$-アル キル誘導休它生成することが知られている1)。この特異的な反応 はラクタム形ーラクチム形（ケト形-オキシ形）の互変異性に起因 するものと考えられ，構造に対し，紫外部吸収スペクトル2) 5), 屈折率(6)，イオン化定数7), 双極子能率 ${ }^{8)}$, 赤外線吸収スペクトル 等9)10の測定により検討が加えられており，いずれもラクタム形 (ケト形)であると推論されている。
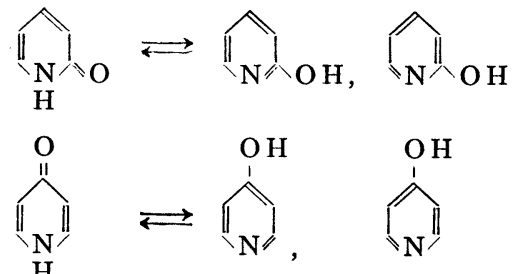

ラクタム形 ラクチム形

2-ピリドンに関しては Penfoldにより結晶解析が行なわれ11), 得られた C-O, C-N, C-C 原子間隔をケト形执よび 4 種のイオ ン形構造の共鳴混成として説明している。

これらの構造決定の备手段は溶液または結晶について行なわれ たもので, 気態, 液態については検討されておらず, この両相に おける構造の知見をうるために赤外線吸収スペクトル測定を試み た。

また固態において 2-ピリドン，4-ピリドンともに結晶 2 形の 存在することをみいだした。2-ピリドン，4-ピリドンともに 12 原子からなり，基準振動の計算は容易でなく，全スペクトル線の 解析は困難なので, 重水素化沶よび偏光赤外線吸収スペクトルの 異方性から結晶 2 形およびスペクトル線の帰属について若干の知 見を得ようとした。

\section{2 赤外線吸収スペクトルの測定*}

a 2-ピリドン: $\mathrm{mp} 106^{\circ} \mathrm{C}_{\text {。 }}$

分析値 C $62.95 \%, \mathrm{H} 5.20 \%, \mathrm{~N} 14.70 \%$

$\mathrm{C}_{5} \mathrm{H}_{5} \mathrm{NO}$ としての

計算值 C $63.15 \%, \mathrm{H} 5.30 \%$, N $14.73 \%$

1) K. Auwers, Ber. 64, 2111 (1930).

2) F. Bakar, E. C. C. Baley, J. Chem. Soc. 91, 1122 (1907).

3) H. Specker, Ber. 75, 1338 (1942).

4) G. W. Ewing, E. A. Steck, J. Am. Chem. Soc. 68, 2181(1946).

5) J. A. Berson, ibid. 15, 352 (1953).

6) K. Auwers, $Z$. phys. Chem. A 164, 33 (1933).

7) A. Phillips, 14th International Congress of Chem. (1955)Zürich.

8) D. G. Leis, B. C. Curran, J. Am. Chem. Soc. 67, 79 (1945).

9）於劸, 大迫, “赤外線吸収スペクトルにおけるピニロジー”，化学の領域增 刊「赤外線财収スペクトル」筑 2 集 p. 181.

10）進藤, “ピリシン系化合物の赤外線败収スペクトル”，化学の領域增刊「赤 外線吸収スペクト儿」第 3 集 p. 163.

11) B. P. Penfold, Acta. Cryst. B, 591 (1953).

* 試料は大日本製楽株式会社研究部西村温樹氏から恵与されたものである. b 4-ピリドン: $\mathrm{mp} 148^{\circ} \mathrm{C}$ 。

分析值 C $62.85 \%, \mathrm{H} 5.15 \%, \mathrm{~N} 14.50 \%$ $\mathrm{C}_{5} \mathrm{H}_{5} \mathrm{NO}$ としての

計算值 C $63.15 \%, \mathrm{H} 5.30 \%, \mathrm{~N} 14.73 \%$

c 2-ピリドン，4-ピリドン重水菜化合物：通常の方法により 試料を, 重水に溶解し重水素交換を行ない, $2 \sim 3$ 日後 $2 \mathrm{mmHg}$ 減圧下 $50^{\circ} \mathrm{C} て ゙$ 重水を蒸発, 乾燥して測定試料とした。

\section{1 気態の赤外線吸収スペクトル}

$5 \mathrm{~cm}$ の加熱用ガスセルを用い，常圧で加熱し，気態となるの を確認して測定した。2-ピリドンは測定に再現性があるが*1，4ピリドンでは試料の分解をともなうために再現性悪く結果が不完 全なのでこの報告では除く。

\section{2 液態の赤外線吸収スペクトル}

食塩板, 臭化カリウム板にはさんだ試料を加熱溶融し, 融点よ りわずかに高い温度 (2-ピリドン, 約 $130^{\circ} \mathrm{C}, 4-$ ピリドン, 約 $\left.165^{\circ} \mathrm{C}\right)$ にたもち測定した。

\section{3 固態の赤外線吸収スペクトル}

a 結晶 2 形: 2-ピリドン, 4-ピリドンともに溶媒から再結晶 によって得られる結晶は高融点結晶*2である。低融点結唱*2 2 加 熱溶融した試料を徐々に冷却する場合に得られる。

測定試料は食塩板あるいは臭化カリウム板にはさんだ溶融試料 を冷却してうるが，低融点形はそのまま放冷して析出させ，高融 点形は高融点形の結晶種を加え, 融点のわずか下の温度に長時間 たもち, 全結晶が高融点形となるのをスペクトル測定により確認 する。

b 偏光赤外線吸収スペクトルの測定: 溶融した試料をはさえ だ食塩板あるいは臭化カリウム板の一方の端を加熱し, 他端をつ めたい金属板に密着させ, 結晶の伸長方向が平行にならぶように して測定試料とした。

偏光子（厚さ $1 \mathrm{~mm}$ の塩化銀 6 枚からなるもの） 2 個を用い, 試料側と reference beam 側とに 1 個ずつおき, 偏光子による 入射光の損失を補償して测定した。なお $I_{0}$ 線は測定のつど検討 した。

測定試料は結晶の伸長方向とスリットの縦軸と平行するように おき, 入射赤外線の偏光の電父べクトルの結晶伸長方向と平行の 場合を $/ /$ ，垂淔の場命を」として図示した。

なお分光器は Perkin-Elmer 21 形分光器を用いた。

\section{3 測定結果の考察}

\section{1 気態スペクトル}

図 1 および表 1 にみられるように2-ピリドンの気態の強いス ペクトル線 $769 \mathrm{~s}, 908 \mathrm{~m}, 1253 \mathrm{~m}, 1472 \mathrm{~m}, 1595 \mathrm{~cm}^{-1} \mathrm{~m}$ は液 態の $768 \mathrm{~s}, 902 \mathrm{mb}, 1220 \mathrm{~s}, 1466 \mathrm{~m}, 1597 \mathrm{~cm}^{-1} \mathrm{~s}$ とそれぞれ 対応がつき,かつ $1716 \mathrm{~cm}^{-1}$ に強いスペクトル線がみられる。

*1 銅-コンスタンタン熱電対によるミリボルトメーターの読みから $290^{\circ} \sim 300^{\circ}$ C に加熱した。

*2 2-ピリドン, 高融点結晶 $\mathrm{mp} 106^{\circ} \mathrm{C}$, 低融点結晶 $\mathrm{mp} 96^{\circ} \mathrm{C}$. 4-ピリドン, 高融点結晶 $\mathrm{mp} 148^{\circ} \mathrm{C}$, 低融点結晶 $\mathrm{mp} 131^{\circ} \sim 132^{\circ} \mathrm{C}$. 


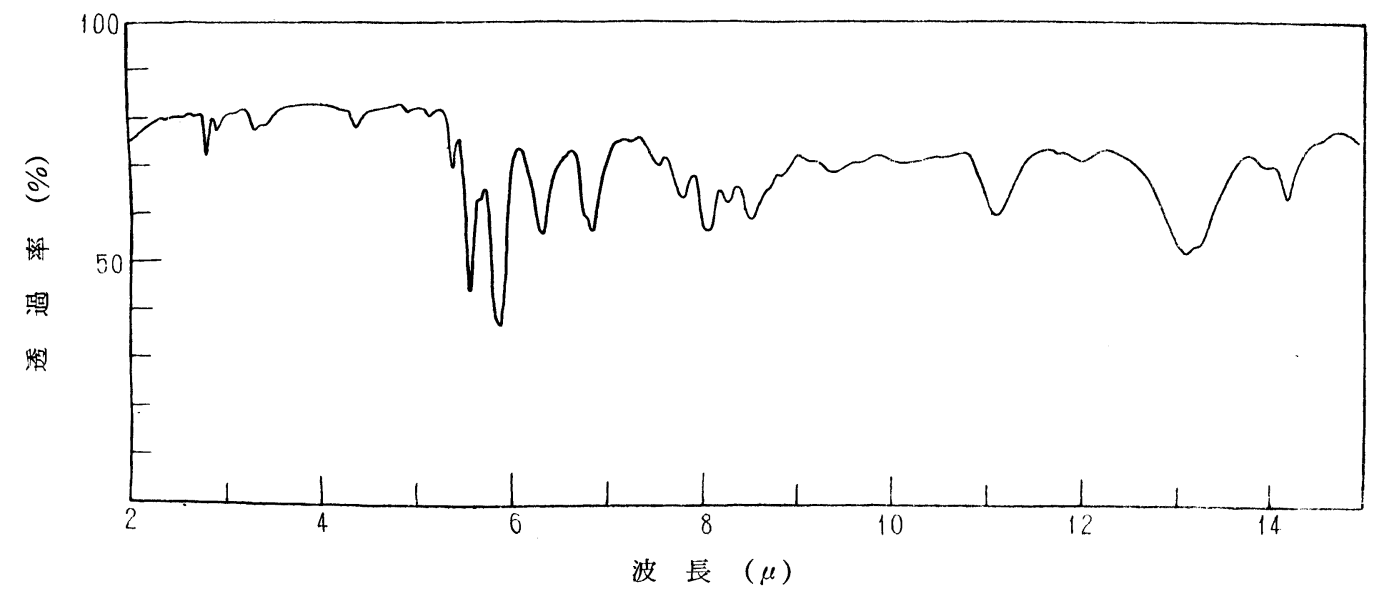

园 12 2-ピリドン 気態

表 12 -ピリ ドン

\begin{tabular}{|c|c|c|c|c|c|c|}
\hline & \multicolumn{2}{|c|}{$\mathrm{N}-\mathrm{H}$ 化 合 物 } & \multirow[b]{2}{*}{ 熊 } & \multirow[b]{2}{*}{ 液 態 } & \multicolumn{2}{|c|}{$N-D$ 化 合 物 } \\
\hline 気 態 & 液 態 & 固 & & & 固 & 態 \\
\hline$\left(\mathrm{cm}^{-1}\right)$ & $\left(\mathrm{cm}^{-1}\right)$ & $\begin{array}{l}\text { 低融点 } \\
\left(\mathrm{cm}^{-1}\right)\end{array}$ & $\begin{array}{l}\text { 高融点 } \\
\left(\mathrm{cm}^{-1}\right)\end{array}$ & $\left(\mathrm{cm}^{-1}\right)$ & $\begin{array}{l}\text { 低融点 } \\
\left(\mathrm{cm}^{-1}\right)\end{array}$ & $\begin{array}{l}\text { 高融点 } \\
\left(\mathrm{cm}^{-1}\right)\end{array}$ \\
\hline \multicolumn{7}{|l|}{$3623 w$} \\
\hline $3460 \mathrm{vw}$ & & $3268 \mathrm{w}$ & & & & \\
\hline \multirow[t]{8}{*}{$3030 \mathrm{w}$} & $3077 \mathrm{~s}$ & $3086 \mathrm{wsh}$ & $3077 \mathrm{~s}$ & $3083 \mathrm{~m}$ & $3074 \mathrm{~m}$ & $3074 \mathrm{~m}$ \\
\hline & & $3040 \mathrm{~s}$ & $3012 \mathrm{~s}$ & $3037 \mathrm{sh}$ & $3009 \mathrm{sh}$ & $3009 \mathrm{sh}$ \\
\hline & $2967 \mathrm{~s}$ & $2941 \mathrm{~s}$ & $2941 \mathrm{sh}$ & & & $2948 \mathrm{sh}$ \\
\hline & $2857 \mathrm{sh}$ & $2825 \mathrm{sh}$ & $2857 \mathrm{sh}$ & & $2768 \mathrm{vw}$ & \\
\hline & & $2717 \mathrm{w}$ & $2695 \mathrm{sh}$ & & $2702 \mathrm{vw}$ & $2631 \mathrm{sh}$ \\
\hline & & & $2618 \mathrm{sh}$ & $2617 \mathrm{w}$ & $2617 \mathrm{vw}$ & \\
\hline & $2475 \mathrm{w}$ & $2488 \mathrm{w}$ & $2519 \mathrm{w}$ & $2537 \mathrm{sh}$ & $2570 \mathrm{vw}$ & $2550 \mathrm{w}$ \\
\hline & & & $2415 \mathrm{w}$ & $(2469 \mathrm{sh})$ & $2459 \mathrm{w}$ & $2457 \mathrm{sh}$ \\
\hline \multirow[t]{5}{*}{$2297 \mathrm{w}$} & $(2347)$ & & $2370 \mathrm{w}$ & $2336 \mathrm{sh}$ & 2370 sh & 2381sh \\
\hline & & $2268 \mathrm{w}$ & $2247 \mathrm{w}$ & $2289 \mathrm{~s}$ & $2283 \mathrm{~s}$ & $2273 \mathrm{~s}$ \\
\hline & & & & $2237 \mathrm{~s}$ & $2227 \mathrm{~s}$ & $2227 \mathrm{~s}$ \\
\hline & & $2079 w$ & $2049 v w$ & $2184 \mathrm{sh}$ & $2088 \mathrm{sh}$ & $2088 \mathrm{sh}$ \\
\hline & & & $1980 \mathrm{w}$ & $1993 \mathrm{sh}$ & & $2014 \mathrm{vw}$ \\
\hline \multirow[t]{3}{*}{$1955 \mathrm{vw}$} & $1957 \mathrm{w}$ & $1961 \mathrm{w}$ & & & $1973 \mathrm{w}$ & $1985 \mathrm{w}$ \\
\hline & & & $1919 \mathrm{w}$ & $1935 \mathrm{sh}$ & & $1920 \mathrm{vw}$ \\
\hline & & & & & $1896 \mathrm{w}$ & $1895 \mathrm{w}$ \\
\hline $1871 \mathrm{w}$ & $1838 w$ & $1859 \mathrm{~m}$ & $1855 \mathrm{w}$ & $1853 w$ & $1853 \mathrm{w}$ & $1850 \mathrm{w}$ \\
\hline $1810 \mathrm{~s}$ & & $1832 \mathrm{wsh}$ & $1821 \mathrm{w}$ & & $1813 w$ & $1813 w$ \\
\hline $1752 \mathrm{vw}$ & $1761 \mathrm{w}$ & & $1767 \mathrm{vw}$ & $1797 \mathrm{vw}$ & $1765 w$ & $1768 \mathrm{w}$ \\
\hline $1731 \mathrm{sh}$ & & & & $1765 \mathrm{vw}$ & & $1728 \mathrm{sh}$ \\
\hline \multirow[t]{4}{*}{$1716 \mathrm{~s}$} & $1678 \mathrm{sh}$ & $1689 \mathrm{sh}$ & $1684 \mathrm{sh}$ & & $1680 \mathrm{~s}$ & \\
\hline & $1653 \mathrm{~s}$ & $1667 \mathrm{~s}$ & $1653 \mathrm{~s}$ & $1655 \mathrm{~s}$ & $1663 \mathrm{~s}$ & $1668 \mathrm{w}$ \\
\hline & & $1653 \mathrm{wsh}$ & & & $1628 \mathrm{w}$ & $1646 \mathrm{~s}$ \\
\hline & & $1618 \mathrm{~s}$ & $1608 \mathrm{~s}$ & & & $1609 \mathrm{sh}$ \\
\hline $1595 \mathrm{~m}$ & $1597 \mathrm{~s}$ & & & & & \\
\hline $1546 \mathrm{sh}$ & $1538 \mathrm{~s}$ & $1546 \mathrm{~s}$ & $1567 \mathrm{w}$ & $1576 \mathrm{~s}$ & $1576 \mathrm{~s}$ & $1584 \mathrm{~m}$ \\
\hline $1513 v w$ & & & $1534 \mathrm{~s}$ & $1542 \mathrm{sh}$ & $1545 \mathrm{w}$ & $1535 \mathrm{~s}$ \\
\hline \multirow[t]{5}{*}{$1472 \mathrm{~m}$} & $1466 \mathrm{~m}$ & $1475 \mathrm{~s}$ & $1481 \mathrm{vw}$ & $1479 \mathrm{vw}$ & $1473 w$ & $1468 \mathrm{sh}$ \\
\hline & $1431 \mathrm{~s}$ & $1447 \mathrm{~s}$ & $1456 \mathrm{~s}$ & $1453 \mathrm{~m}$ & $1453 w$ & $1456 \mathrm{~m}$ \\
\hline & & & & $1441 \mathrm{~m}$ & & $1443 \mathrm{sh}$ \\
\hline & & $1408 \mathrm{vw}$ & $1418 \mathrm{~m}$ & & & $1427 \mathrm{sh}$ \\
\hline & $1372 \mathrm{w}$ & $1374 \mathrm{~m}$ & $1364 \mathrm{w}$ & & $1391 \mathrm{~m}$ & $1387 \mathrm{w}$ \\
\hline \multirow[t]{2}{*}{$1339 w$} & & & $1318 \mathrm{vw}$ & & $1312 \mathrm{~m}$ & $1332 \mathrm{w}$ \\
\hline & $1304 \mathrm{w}$ & & & $1307 \mathrm{~s}$ & $1307 \mathrm{sh}$ & $1310 \mathrm{~m}$ \\
\hline $1297 \mathrm{w}$ & & & $1285 \mathrm{vw}$ & & $1260 \mathrm{vw}$ & \\
\hline $1253 \mathrm{~m}$ & $1242 \mathrm{sh}$ & $1261 \mathrm{w}$ & $1258 \mathrm{wsh}$ & $1240 \mathrm{~m}$ & $1246 \mathrm{~m}$ & $1235 \mathrm{~m}$ \\
\hline $1218 \mathrm{w}$ & $1220 \mathrm{~s}$ & $1247 \mathrm{~s}$ & $1239 \mathrm{~s}$ & $1223 \mathrm{sh}$ & $1232 \mathrm{sh}$ & $1228 \mathrm{sh}$ \\
\hline
\end{tabular}




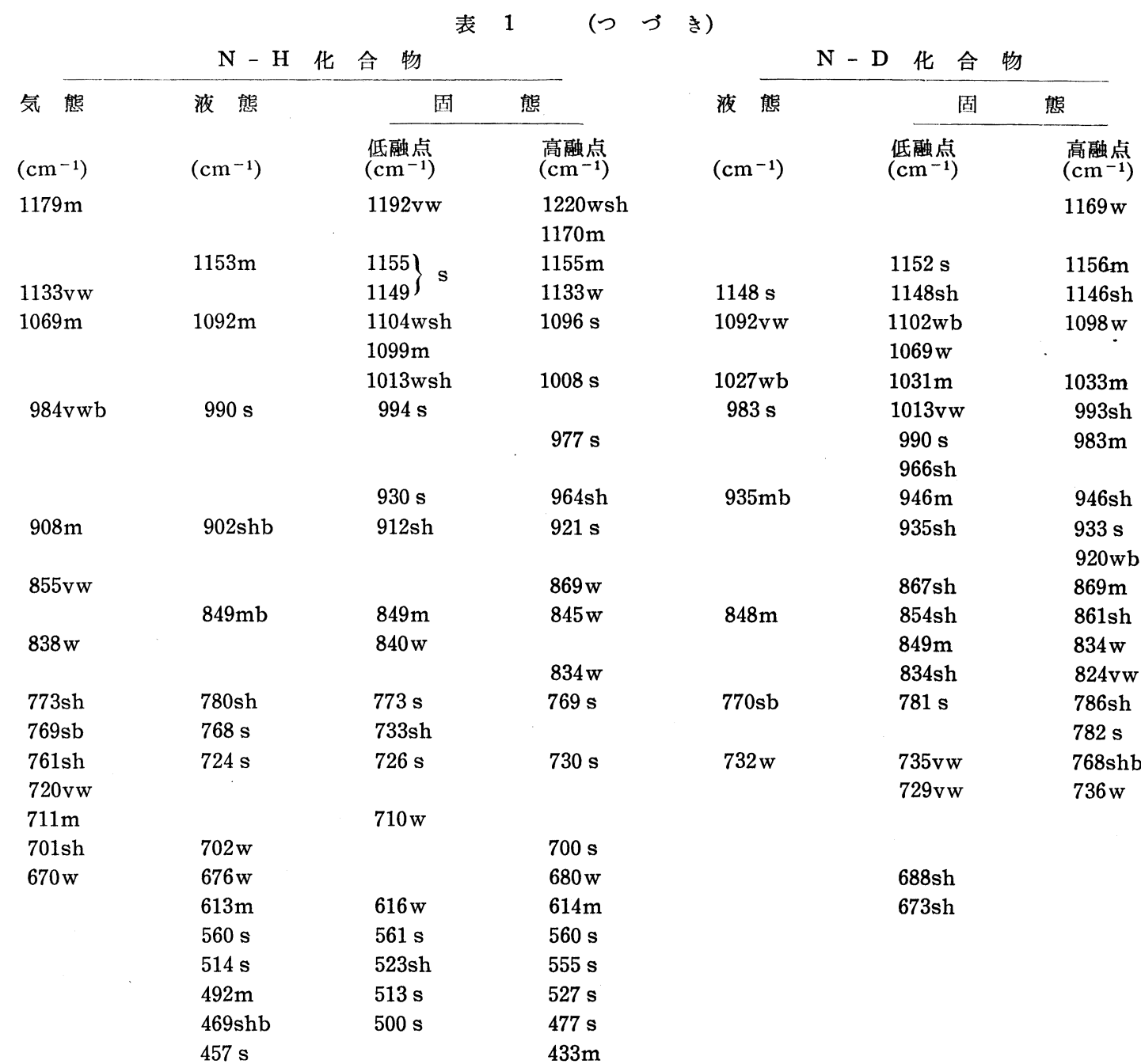

ケト形構造の 2-ピリドンはシス形のアミドとも考えられ，一 置換アミドに関する宮沢 ${ }^{12}$ の気態の測定結果を参考にすると $N$ -

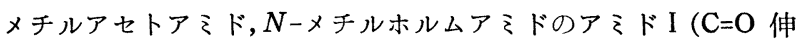
縮の主として寄与する振動）のスペクトル線は $1718 〜 1730 \mathrm{~cm}^{-1}$ にみられ, 気態の 2 -ピリドンの $1716 \mathrm{~cm}^{-1}$ はアミドと同様遊離 の $\mathrm{C}=\mathrm{O}$ 伸縮振動に帰属するのが妥当であろう。また気態スペク トルはケト形構造と推論される固態スペクトルとも対応するの で，2-ピリドンは気態においてもケト形構造をとるものと推論さ れる。

—4-ピリドンにおいても $1740 \mathrm{~cm}^{-1}$ 付近に遊離の $\mathrm{C}=\mathrm{O}$ 伸縮 振動とみられる強いスペクトル線が観測されるが, 試料の分解が おこるためデータは不完全である。一

\section{2 液態スペクトル}

2-ピリドン，4-ピリドンの液態スペクトルはそれぞれの固態 スペクトルにみられる小さい分枝のうしなわれた幅の広いスペク トル線を与え，スペクトル線の波数および強度が固態スペクトル 線と対応しており, 表 $1 \sim 2$ からみられるように $\mathrm{C}=\mathrm{O}$ 伸縮振動

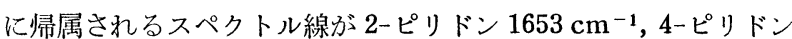
$1632 \mathrm{~cm}^{-1}$ にみられる。したがって 2-ピリドン，4-ピリドンい ずれも液態においてもケト形構造をとると推論され，NH 伸縮振 動は水素絬合により低波数にシフトし， $3000 \mathrm{~cm}^{-1}$ 付近で $\mathrm{C}-\mathrm{H}$ 伸縮振動と重なると考えられる。

12) 宮沢, 日化 71, 321 (1956).

\section{3 固態スペクトル}

2-ピリドン, 4-ピリドンの低融点形, 高融点形のスペクトルは 若干の差がみられ，2-ピリドンにおける $1653 \sim 1690 \mathrm{~cm}^{-1}, 1000$ $\mathrm{cm}^{-1}$ 付近, $500 \mathrm{~cm}^{-1}$ 付近, 4-ピリドンにおける 1500〜1650, $920 \sim 1030,840 \mathrm{~cm}^{-1}$ 付近, $2500 \sim 3000 \mathrm{~cm}^{-1}$ でいちじるしい が，いずれも $1650 \mathrm{~cm}^{-1}$ *3 付近に $\mathrm{C}=\mathrm{O}$ 伸縮振動に帰属される スペクトル線を有し，かつ差のみられるスペクトル線も分枝の差 程度で, 強度の強いスペクトル線の波数差はいちじるしくない。 したがっていずれもケト形構造を有する分子の配列を異にする結 晶多形と考えられる。

\subsection{NH 変角振勒の軍属*4}

ケト形構造をとる場合 $\mathrm{NH}$ の結合を有することになり， NH に関する振動のスペクトル線帰属を明らかにする必要がある。こ の点を重水素化, 偏光赤外線吸収の異方性から検封する。

3.4 .1 重水素化によるスペクトル変化からの検討：元来 $\mathrm{NH}$

*3 2-ピリドンの高融点形の $1653 \mathrm{~cm}^{-1}$ のスペクトル線はクロロホルム溶液の $1661 \mathrm{~cm}^{-1}$ 亿対応する．またアセトニトリル溶液では $1661 \mathrm{~cm}^{-1}$ と 1681 $\mathrm{cm}^{-1}$ の 2 本に分枝し, 濃厚淠液では $1661 \mathrm{~cm}^{-1}$ が強く, $1681 \mathrm{~cm}^{-1}$ は肩 として出ているが，希粎すると強度が逆転する. $1661 \mathrm{~cm}^{-1}$ は dimer 的 結合の $\mathrm{C}=\mathrm{O}$ 伸縮とみられる。

*4 NH, ND 伸縮振動は副次吸収带が多く，乙の理由についてはわからない

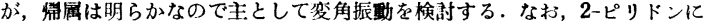
おいては液態の NH 伸縮振動は高融点形, 低融点形の NH 伸縮振動の中 間の波数值を有する点特長があり，4-ピリドンでは低融点形で NH 伸縮振 動がいちしるしく長波長に出現し，水素結合の強い分子配列を有すると考え られ興味がある。 
変角振動と相互作用のある振動あるいは ND 変㓩振動と新たに相互作用を生ずる 振動では，重水素化によってシフトし， 重水素化によるスペクトル線の变化は N H変角に関する振動だけではないため に帰属は困難になる。2-ピリドン，4-ピ リドンでは液態の主要スペクトル線は固 態スペクトル線と強度の大きいスペクト ル線で一致して打り，分枝が少ないため に重水素化の变化を追跡するに都合がよ い。液態および結晶 2 形の重水素化によ るスペクトル変化をまとめてみる。

\section{2-ピリドン}

1. 重水素化により消失するスペクト ル線

a 液態 $1597 \mathrm{~cm}^{-1}$, 低融点形 1618 $\mathrm{cm}^{-1}$, 高融点形 $1608 \mathrm{~cm}^{-1}$

b 液態 $1092 \mathrm{~cm}^{-1}$, 低蚽点形 1099 $\mathrm{cm}^{-1}$, 高融点形 $1096 \mathrm{~cm}^{-1}$

c 液態 $724 \mathrm{~cm}^{-1}$, 低融点形 726 $\mathrm{cm}^{-1}$, 高融点形 $730 \mathrm{~cm}^{-1}$

2. 重水素化により出現するスペクト ル線

a 液態 $1307 \mathrm{~cm}^{-1}$, 低融点形 1312 $\mathrm{cm}^{-1}$, 高融点形 $1310 \mathrm{~cm}^{-1}$

b 液態 $1148 \mathrm{~cm}^{-1}$, 低融点形 1152 $\mathrm{cm}^{-1}$, 高融点形 $1156 \mathrm{~cm}^{-1}$ $\mathrm{c}^{* 5}$ 液態 $732 \mathrm{~cm}^{-1}$, 低融点形 735 $\mathrm{cm}^{-1}$, 高融点形 $736 \mathrm{~cm}^{-1}$

d 未測定であるが食塩プリズム領 域からも出現の明らかな $650 \mathrm{~cm}^{-1}$ より低いスペクトル線

3. 重水素化により液態スペクトルの 強度は娍少するが低融点形, 高融点 形でスペクトル線の一致しないもの $1430 \mathrm{~cm}^{-1}$ 扣よび $1220 \mathrm{~cm}^{-1}$ 付近 のスペクトル線

4. 重水素化に上り液態スペクトルの 強度は增加するが低融点形, 高融点 形でスペクトル線の一致しないもの $930 \mathrm{~cm}^{-1}$ 付近のスペクトル線

以上の結果から $\mathrm{NH}$ 面内変角振動と ND 面内変角振動の可能性ある組久合 わせは
1) $1597 \longrightarrow 1310 \mathrm{~cm}^{-1}$
$\nu^{\prime} / \nu$
2) $1430 \longrightarrow 930$
1.22
3) $1220 \longrightarrow 930$
1.53
1.31
4) $1220 \longrightarrow 732$
1.67
5 ) $1092 \longrightarrow 732$
1.49
6 ) $1597 \longrightarrow 1150$
1.39

*5 いずれも非常に弱い，

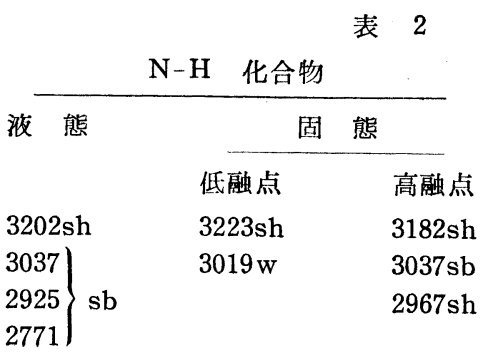

$2675 \mathrm{sh}$

$2494 \mathrm{sh}$

$2363 \mathrm{sh}$

$2011 w b$

1915wb

$1860 \mathrm{sh}$

$1771 \mathrm{sh}$

1777 wb

$1722 \mathrm{sh}$

$1645 \mathrm{sh}$

$1632 \mathrm{~s}$

$1515 \mathrm{sb}$

$1452 \mathrm{sh}$

$1390 \mathrm{~s}$

$1287 \mathrm{~m}$

$1241 \mathrm{w}$

$1206 \mathrm{w}$

$1182 \mathrm{~s}$

$1069 \mathrm{w}$

$1028 \mathrm{w}$

$999 \mathrm{~m}$

970 sb

$920 \mathrm{w}$

840 sb

$726 \mathrm{w}$

$726 \mathrm{~m}$

$640 \mathrm{vw}$

$558 \mathrm{~m}$

$533 \mathrm{~m}$

$518 \mathrm{~s}$.

$498 \mathrm{~s}$

$1970 \mathrm{w}$

$1922 \mathrm{w}$

$1853 \mathrm{w}$

$1826 \mathrm{w}$

$1702 \mathrm{sh}$

$1667 \mathrm{sh}$

$1639 \mathrm{~s}$

1580 ssh

$1564 \mathrm{~s}$

$1549 \mathrm{~s}$

$1432 \mathrm{sh}$

$1509 \mathrm{~s}$

$1463 \mathrm{sh}$

$1394 \mathrm{~m}$

$1398 \mathrm{~m}$

1361sh

$1322 \mathrm{vw}$

$1280 \mathrm{~s}$

$1245 \mathrm{w}$

$1230 \mathrm{sh}$

1192s

$1175 \mathrm{~s}$

$1033 \mathrm{~m}$

$992 \mathrm{~m}$

$962 \mathrm{~m}$

$926 \mathrm{~s}$

$856 \mathrm{sb}$

830sh

$815 \mathrm{sb}$

$726 \mathrm{w}$

$629 \mathrm{w}$

$553 \mathrm{~s}$

538 ssh

$498 \mathrm{~s}$ $4-ヒ^{\circ}$

$\frac{\mathrm{N}-\mathrm{D} \text { 化合物 }}{\text { 液 態 固 態 }}$

$\begin{array}{lll} & \text { 低融点 } & \text { 高融点 } \\ 3215 \mathrm{w} & 3236 \mathrm{sh} & 3226 \mathrm{w} \\ & 3115 \mathrm{sh} & \\ 3058 \mathrm{~s} & 3067 \mathrm{~m} & 3067 \mathrm{~m} \\ 2933 \mathrm{~s} & 2913 \mathrm{vw} & 2959 \mathrm{~m} \\ 2849 \mathrm{sh} & 2847 \mathrm{vw} & 2874 \mathrm{vw} \\ 2778 \mathrm{shb} & & 2717 \mathrm{vw} \\ 2632 \mathrm{wb} & 2623 \mathrm{w} & 2632 \mathrm{vw} \\ 2481 \mathrm{w} & 2498 \mathrm{w} & 2475 \mathrm{w} \\ (2353) & 2329 \mathrm{w} & 2283 \mathrm{~m} \\ 2262 \mathrm{sh} & & \\ 2198 \mathrm{~s} & 2167 \mathrm{w} & 2242 \mathrm{sh} \\ & & 2105 \mathrm{w} \\ 2092 \mathrm{sh} & 2068 \mathrm{~m} & \end{array}$

$1976 \mathrm{sh} \quad 1978 \mathrm{~m}$

$1754 \mathrm{w}$

$1768 \mathrm{w}$

$1393 \mathrm{~s}$

$1642 \mathrm{~s}$

1667 sh

$1651 \mathrm{sh}$

$1632 \mathrm{~s}$

1984 wsh

$1953 \mathrm{w}$

$1912 \mathrm{w}$

$1887 \mathrm{w}$

$1862 \mathrm{w}$

$1828 \mathrm{w}$

$1783 \mathrm{w}$

1748 w

$1715 \mathrm{vw}$

$1675 \mathrm{sh}$

$1639 \mathrm{~s}$

$1595 \mathrm{~m}$

$1564 \mathrm{sh} \quad 1563 \mathrm{sh}$

$1527 \mathrm{sb} \quad 1546 \mathrm{sh} \quad 1546 \mathrm{sh}$

$1519 \mathrm{~s} \quad 1508 \mathrm{~s}$

$1466 \mathrm{sh} \quad 1456 \mathrm{w}$

$1410 \mathrm{vwsh}$

$1399 \mathrm{~m}$

$1387 \mathrm{sh}$

$1350 \mathrm{~s}$

$1397 \mathrm{~m}$

$\begin{array}{ll}1357 \mathrm{~s} & 1357 \mathrm{~s} \\ 1321 \mathrm{w} & 1319 \mathrm{vw}\end{array}$

$1295 \mathrm{~s} \quad 1302 \mathrm{~m} \quad 1280 \mathrm{~m}$

$1247 \mathrm{vw} \quad 1255 \mathrm{w} \quad 1258 \mathrm{~m}$

$1208 \mathrm{w} \quad 1224 \mathrm{w} \quad 1229 \mathrm{~m}$

$1194 \mathrm{~s} \quad 1192 \mathrm{~m}$

$1188 \mathrm{sh}$

$1182 \mathrm{~s}$

$1179 \mathrm{sh}$

$1151 \mathrm{~m}$

$1117 \mathrm{w}$

$1132 \mathrm{w}$

$1145 \mathrm{w}$

$1103 \mathrm{sh} \quad 1121 \mathrm{w}$

$1073 \mathrm{w} \quad 1086 \mathrm{~m} \quad 1074 \mathrm{w}$

$1050 \mathrm{vw}$

$1025 \mathrm{~m}$

$1031 \mathrm{~m}$

992sh

$982 \mathrm{~m}$

$985 \mathrm{sb}$

$969 \mathrm{~m}$

$949 \mathrm{~m}$

970 sh

$919 w b$

$930 \mathrm{~m}$

$937 \mathrm{wb}$

$862 \mathrm{~s}$

840 wsh

826 sh

$847 \mathrm{sb}$

$829 \mathrm{vw}$

$819 \mathrm{w}$

$720 \mathrm{w}$

$737 \mathrm{~m}$

$763 \mathrm{w}$

$627 \mathrm{wb}$

$711 \mathrm{sb}$

$724 \mathrm{w}$

$561 \mathrm{wb}$

$633 \mathrm{w}$

$639 \mathrm{~s}$

$611 \mathrm{vw} \quad 623 \mathrm{~s}$

$553 \mathrm{~m} \quad 548 \mathrm{sh}$

$532 \mathrm{~s}$ 
表 2 (つづき)

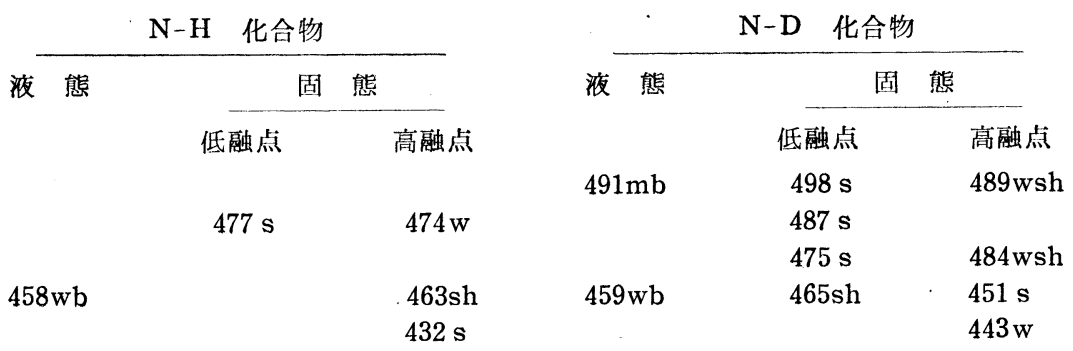

表 3 偏光赤外線吸収スパクトル

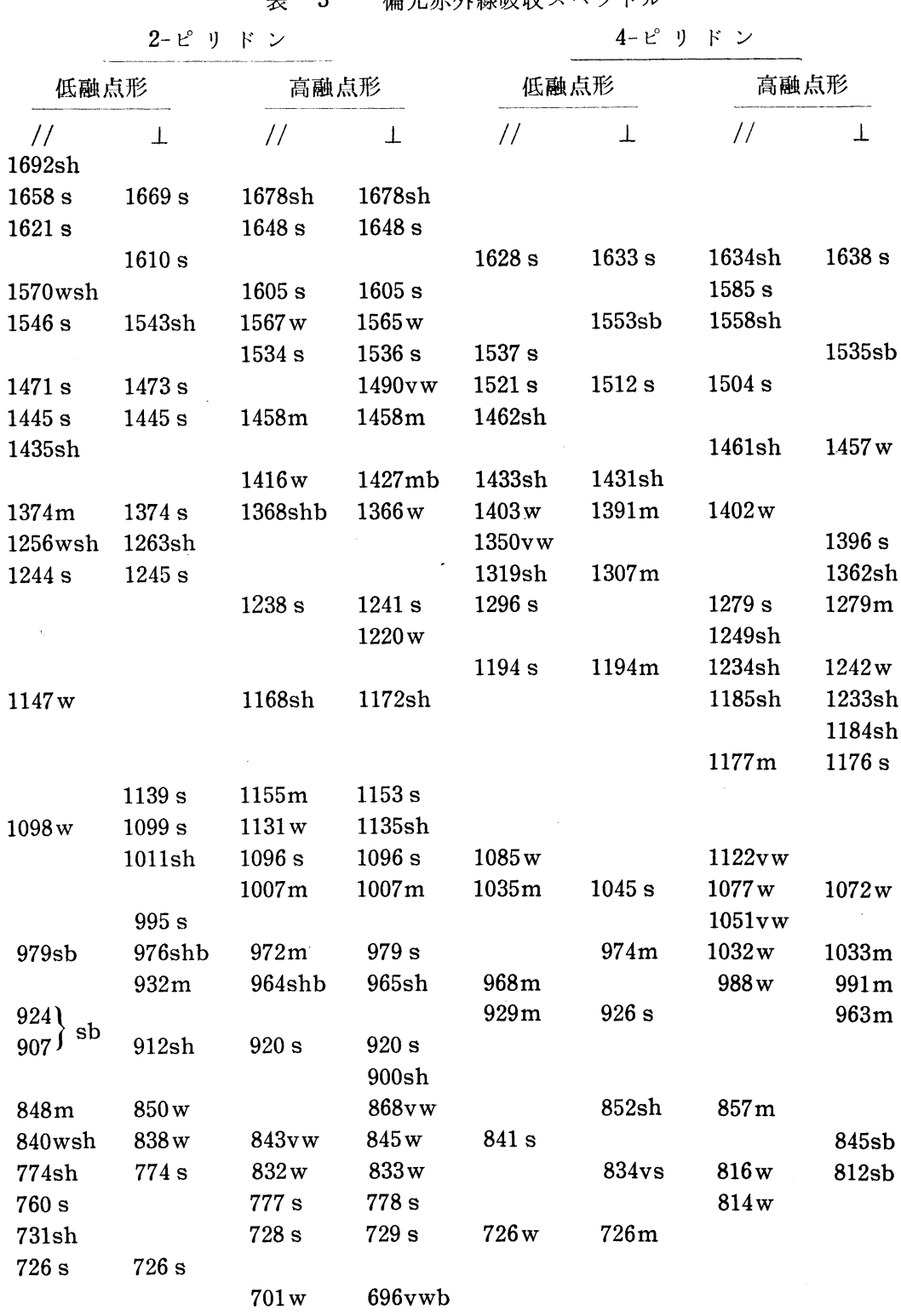

$\nu / 2$

7) $1430 \longrightarrow 1150 \mathrm{~cm}^{-1} 1.24 \quad 8$ ) $1092 \longrightarrow 930 \mathrm{~cm}^{-1} \quad 1.07$

このうちレ'/2の值から可能性のあるのは 1), 3),6) および 7 )

であるが，偏光赤外線吸収の異方性からさらに検討を要する。

な打重水素化により消失する $784 \mathrm{~cm}^{-1}$ は $\mathrm{NH}$ 面外变角振動と

中るのが妥当であろう。

4-ピリドン

液態では重水素化により消失するスペクトル線は顕著にはみら
れず, $1390 \mathrm{~cm}^{-1}$ がいくらか強度を減ず るかという程度で, 出現するスペクトル 線は1350，1117，627，561 $\mathrm{cm}^{-1}$ がみら れ，また $985 \mathrm{~cm}^{-1}$ は強度が増したかと みられるが，これらのうち $1350 \mathrm{~cm}^{-1}$ だけ強く他は弱い。亦たわずかなスペク トル線の移動もみられる。

固態スペクトルにおいては

1. 重水素化により消失するスペクト ル線
a 高融点形 $1580 \mathrm{~cm}^{-1}$, 低融点形 $1549 \mathrm{~cm}^{-1}$
b 高融点形 $815 \mathrm{~cm}^{-1}$

2. 重水素化により出現するスパクト ル線

a 高融点形 $1357 \mathrm{~cm}^{-1}$, 低融点形 $1357 \mathrm{~cm}^{-1}$

b 高融点形 $639 \mathrm{~cm}^{-1}$, 低融点形 $711 \mathrm{~cm}^{-1}$

3. 重水素化により強度を減ずるとみ られるが低融点形, 高融点形で一致 せぬもの

高融点形 $1394 \mathrm{~cm}^{-1}$, 低融点形 $1398 \mathrm{~cm}^{-1}$

4. 重水素化により出現あるいは移動 を生じたか不分明な高融点形, 低融 点形の一致せ好の

$1000 \mathrm{~cm}^{-1}$ 付近のスペクトル線

$\mathrm{NH}$ 面内変角振動として 2-ピリドン と同様なくみあ゙わせを考えると

1) $\left.\begin{array}{r}1580 \text { (高) } \\ 1549 \text { (低) }\end{array}\right\} \rightarrow 1357 \mathrm{~cm}^{-1} \sim \begin{array}{r}\nu^{\prime} / \nu \\ 1.14\end{array}$

2) 1390 付近 $\longrightarrow 1000 \mathrm{~cm}^{-1}$ 付近 1.39

3) $\left.\begin{array}{r}1580 \\ 1549\end{array}\right\} \rightarrow 1117 \mathrm{~cm}^{-1}$ 付近 $\begin{array}{r}1.39 \\ 1.41\end{array}$

4) 1390 付近 $\longrightarrow 1117 \mathrm{~cm}^{-1}$ 付近 1.24

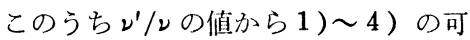
能性が残るのでこれも偏光赤外線吸収の 異方性から検討を要する。

な扮高融点形 $815 \mathrm{~cm}^{-1}$ は $\mathrm{NH}$ 面外 変角振動と考えられ, 重水素化により出 現する $639 \mathrm{~cm}^{-1}$ は対応する ND 面外 変角振動と考えられる。低融点形の重水 素化合物に出現する $711 \mathrm{~cm}^{-1}$ を ND 面 外変角振動とすると $\mathrm{NH}$ 面外变角振動 は強い $\mathrm{CH}$ 面外変角振動 $837 \mathrm{~cm}^{-1}$ に重なるとみられる。

\section{4 .2 偏光赤外線吸収の異方性からの検討}

\section{2-ピリドン}

高融点結晶：Penford の結晶解析の結果から 2-ピリドンの分子 面は結晶の伸長方向ならびにこれと垂直方向いずれにもかた皃き をもち，伸長方向に平行な電気べクトル偏光と垂直な電気べクト ル偏光でいちじるしい吸収の異方性は期待されない。図 2 にみら れるように，ほとんどすべてのスペクトル線は平行，垂直両成分 
がみられこの異方性 加らスペクトル線 の帰属の参考を求以 るのは避当でない。

低融点結晶：図 3 にみられるように吸 収の異方性いちじる 乙く, 振動の transition moment $の$ 方 向により平行成分の ものと垂直成分のも のとが別にみ文れ る。したがって通雨 の結品スペクトルに 打いて禹なっている スペクトル線も，そ の成分から帰属の参 考にしうる。結品解 析の結果がないので 各スペクトル線につ いては十分に検討し 得ないが, $\mathrm{N}-\mathrm{H}$ 伸縮 振動怯平行成分が強 く, 垂直成分がほと えどみられないこと から, NH の transition moment の方 向が $\mathrm{N}-\mathrm{H}$ 結合軸よ りひどくずれないと し，また $\mathrm{CH}$ 面外変 角振動とみられる 924 $907 \mathrm{~cm}^{-1}$ が $\mathrm{NH}$ 伸縮振動と同じ平行成 分をもつととを考虑すると， $\mathrm{NH}$ 伸縮振動， $\mathrm{CH}$ 面外变角振動の いずれとも直交する transition momentをもつ NH面内变角振 動情直成分をもつと考光られる。この観点から垂直成分の強い スペクトル線をみると1610，1473，1445，1374，1139，1099， $932 \mathrm{~cm}^{-1}$ があるが, $1610,1445 \mathrm{~cm}^{-1}$ 以外のスペクトル線はい ずれも重水素化により変化をうけていると考えられない。また重 水素化による検討の項において $\mathrm{NH}$ 面内変角振動として可能性 を考光た低融点形 $1618,1447,1247 \mathrm{~cm}^{-1}$ のうち $1247 \mathrm{~cm}^{-1}$ は $\mathrm{NH}$ 伸縮振動と同じ平行成分を有するので除外でき，結局前 2 者 が可能性が残る。しかし $1447 \mathrm{~cm}^{-1}$ に相当する $1445 \mathrm{~cm}^{-1}$ は吸 収の異方性も顕著でなく，かつ重水素化によるスペクトル線の消 失，出現の点もいちじるしくないので $1610 \mathrm{~cm}^{-1}$ が $\mathrm{NH}$ 面内変 角振動で配向していない結晶では, 平行成分である $1621 \mathrm{~cm}^{-1}$ と 重なり，ピークが $1618 \mathrm{~cm}^{-1}$ に移動しているものとみられる。 ND 面内変角振動としては $1312,1152 \mathrm{~cm}^{-1}$ が考兄られが強度 より前者に帰属するのが妥当であうう。また重水素化により面外 変角振動に帰属される $726 \mathrm{~cm}^{-1}$ は $\mathrm{CH}$ 面外変角振動に䚻属され る $773 \mathrm{~cm}^{-1}$ と同じ平行成分をもつ点で妥当であるう。

\section{4-ピリドン}

高融点結晶：図 4 にみられるように吸収の異方性はいちじるし い。4-ピリドンにおいては $\mathrm{C}=\mathrm{O}$ と $\mathrm{N}-\mathrm{H}$ は分子軸上にあり，

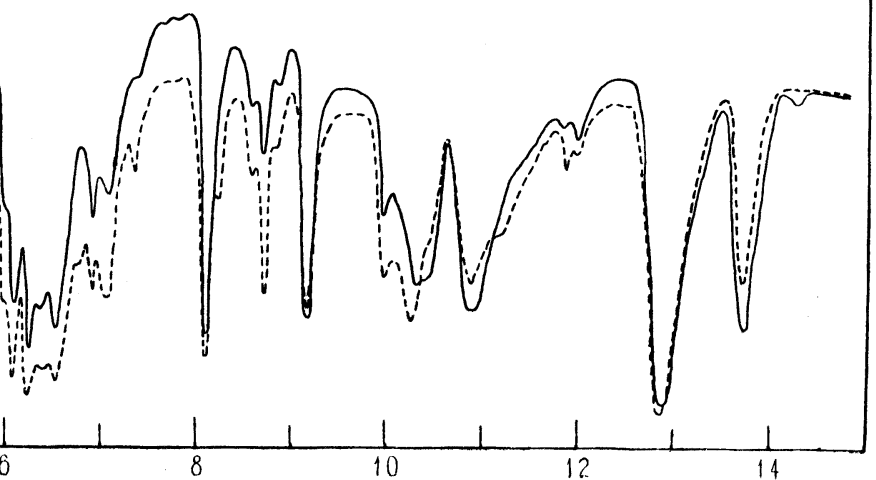

波 長 $(\mu)$ - : // -...-: 1

\section{2-ピリドン商融点結晶偏光赤外}

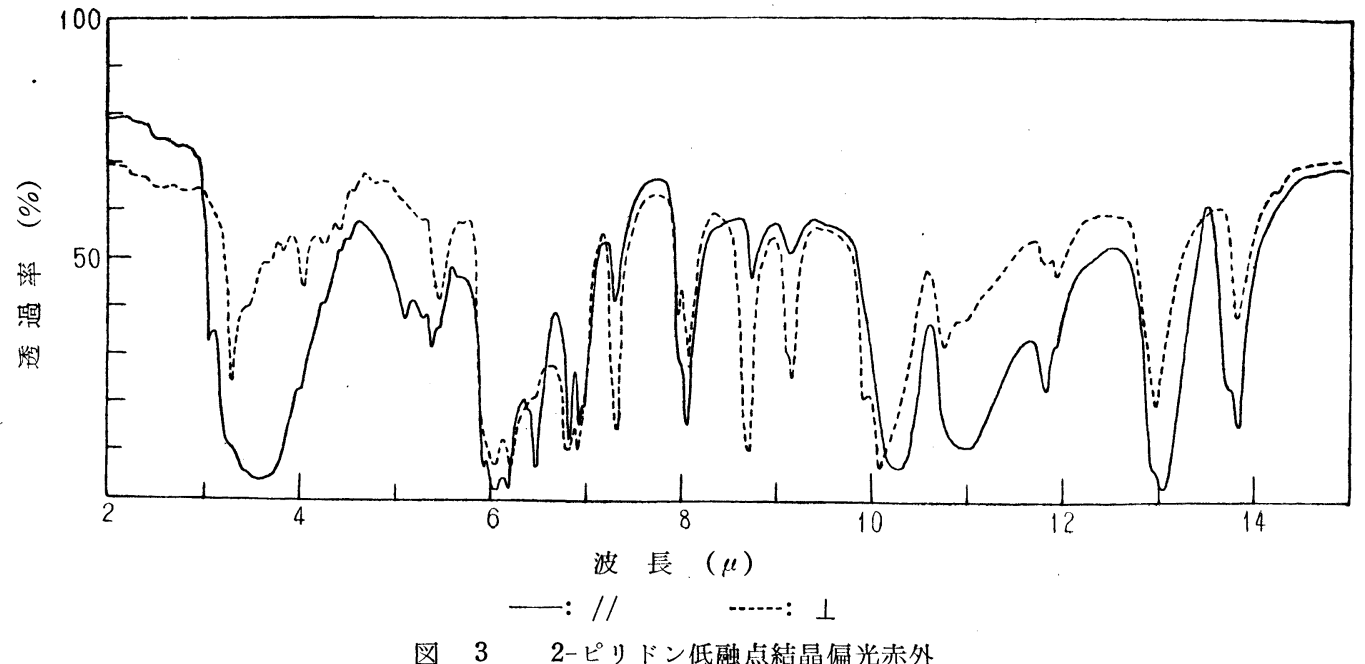

$\mathrm{N}-\mathrm{H}$ 伸縮の transition moment の方向はこの分子軸よりずれ 光ないから $\mathrm{N}-\mathrm{H}$ 伸縮振動と $\mathrm{C}=\mathrm{O}$ 伸縮振動は同一の偏光の成分 をもつことが期待され，測定結果もこれに対芯して $3000 \mathrm{~cm}^{-1}$ 付 近の $\mathrm{NH}$ 伸縮振動乞 $\mathrm{C}=\mathrm{O}$ 伸縮振動に帰属される $1638 \mathrm{~cm}^{-1}$ は 同じ垂直成分をもつが，いずれも平行成分がほとえどみられな い。またこの場合 $\mathrm{CH}$ 面外変角振動に帰属するのが妥当な 856 $\mathrm{cm}^{-1}$ も垂直成分が非常に強く, したがって $\mathrm{N}-\mathrm{H}$ 伸縮, $\mathrm{C}=\mathrm{O}$ 伸縮, $\mathrm{CH}$ 面外変角の各振動のいずれとも直交する transition moment をもつ $\mathrm{NH}$ 面内変角振動は平行成分にみられるはずで ある。

図 4 より平行成分の強いスペクトル線は $1585,1504 * 6,1279$ $\mathrm{cm}^{-1}$ の 3 本であるが, $1504,1279 \mathrm{~cm}^{-1}$ は重水素化によりいち じるしい変化をうけず, また重水素化による検討において可能性 を考光た $1396 \mathrm{~cm}^{-1}$ (液態 $1310 \mathrm{~cm}^{-1}$ ) は $\mathrm{NH}$ 伸縮, $\mathrm{C}=\mathrm{O}$ 伸 縮振動と同じ垂直成分をもつので除外される。したがって 1585 $\mathrm{cm}^{-1}$ は重水素化によるスペクトル変化の点に扔いても一致し NH 面内変角振動に帰属される。

また $\mathrm{NH}$ 面外変角振動は $\mathrm{CH}$ 面外変角振動と同じ成分をもつ $815 \mathrm{~cm}^{-1}$ は重水素化の結果とも一致し妥当である。

*6 4-ピリドンの分子対称 $C_{2 v}$ とすると $A_{1}$ 形 $\mathrm{C}=\mathrm{C}$ 伸縮振動 は $\mathrm{C}=\mathrm{O}$ 伸縮 と同じ成分をもつはずである. 高融点形 $1535 \mathrm{~cm}^{-1}$, 低融点形 $1537 \mathrm{~cm}^{-1}$ は $A_{1} \mathrm{C}=\mathrm{C}$ 伸縮振動とみられる波数がかなり低いのは $\mathrm{C}=\mathrm{O}$ 伸縮との結合 が大きいためであろう. 
低融点結晶：四 5

にみられるようにや

はり異方性は夕られ

るが，この場合は $\mathrm{NH}$ 伸縮, $\mathrm{C}=\mathrm{O}$ 伸縮 振動の異方性注高融 点形結晶ほどいちじ るしくない。また $\mathrm{NH}$ 伸縮振動と $\mathrm{CH}$ 面外変危振動に帰属 される $841 \mathrm{~cm}^{-1}$ と は成分を異にしてお り，結晶の伸長軸の いれかわったことが 考えられるが， NH 伸縮 $\mathrm{C}=\mathrm{O}$ 伸縮振動 は平行成分に強いの で $\mathrm{NH}$ 面内変角 振動注垂成分がつ よいとみられ，この 点からみると 1553 , 1512, 1391, 1307 $\mathrm{cm}^{-1}$ が考兄らる が $1512,1307 \mathrm{~cm}^{-1}$ は重水素化の影響を うけておらず， 1391 $\mathrm{cm}^{-1}$ は高融点形 $1396 \mathrm{~cm}^{-1}$ と同一州 属のスペクトル線と 考えると可能性が除
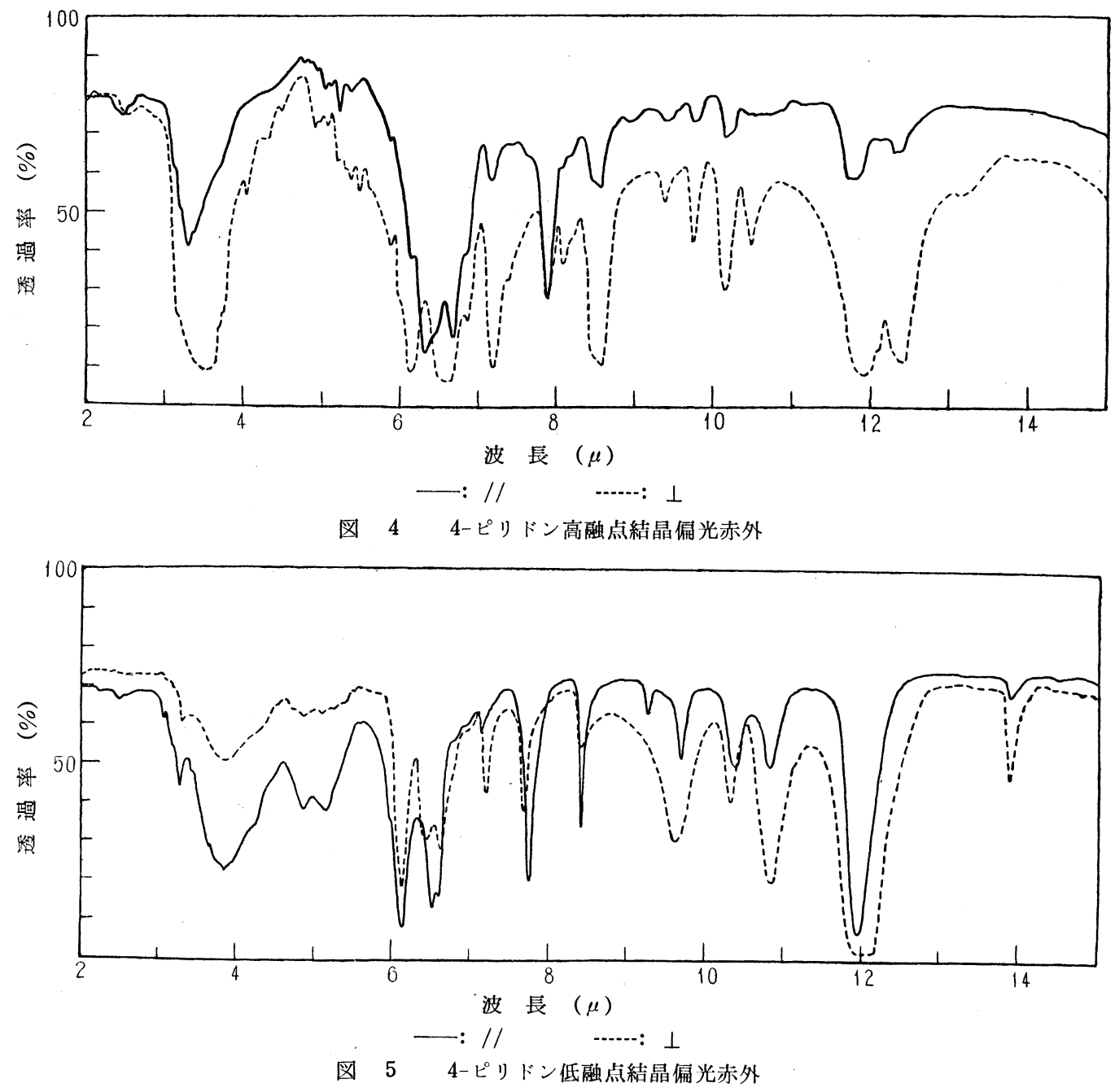

外されるので, $1553 \mathrm{~cm}^{-1}$ が高融点形の $1585 \mathrm{~cm}^{-1}$ と対応する NH 面内変角振動と帰属される。ND面内変角振動はしたがって $1357 \mathrm{~cm}^{-1}$ または $1117 \mathrm{~cm}^{-1}$ 付近が考えられるが, 強度と 2-ピリ ドンとの対応により前者に帰属されよう。

2-ピリドンの低融点形, 4-ピリドンの低融点形, 高融点形いず れも結晶解析の結果が知られていないが，この点が明らかになれ ば偏光赤外線吸収の異方性よりスペクトル線の帰属がさらに明ら かになし得よう。

ND 面内変角振動はシス形アミドである $\delta$-バレロラクタム, ย-カプロラクタム, ジケトピペラシシンで, それぞれ 983, 953, 970 $\mathrm{cm}^{-1}$ で13)，ここに帰属した 2-ピリドン，4-ピリドンの 1310〜 $1350 \mathrm{~cm}^{-1}$ とかなり差がタられ，また $\mathrm{NH}$ 面内变角振動も 1550

〜 $1610 \mathrm{~cm}^{-1}$ と高波数にみられるが, 共鳴混成構造をとると考え られる物質であるため $\mathrm{NH}$ の性質が一般のアミド，アミン類と 異なることによるのであろう。

本研究の一部は東京大学理学部化学教室水島研究公に打いて行 なわれたもので終始想䈆な御指導を睗わった水島三一郎教授, 島 内武彦，市嶋 勲両助教授に心から御礼申上げる。また偏光子を 貸与された大阪大学理学部田所宏行学士に感謝の意を表する。ま た研究ならびに発表の機会を与えられた大日本製薬株式会社学術 部長加藤貞武博士，同研究部長筒井 清博士。同研究部課長於势 真輔博士に厚く感謝申しあげる。

13) T. Miyazawa, T. Shimanouchi, S. Mizushima, J. Chem. Phys. 24, 408 (1956).

\section{1,1,2-トリクロルエタンの基準振動の機械計算}

（昭 和 33 年 8 月 16 日受理）

佐 伯 慎之 助

1,1,2-トリクロルエタンの基準振動の計算を $C_{\mathrm{S}}$ の対称を有する二つの回転異性体について行った。との計算は 6 次元と 11 次 元の行列の固有值問題をとくととに帰するが IBM を用いてその計算を実行し，乙の種の計算機械を用いれば 11 次元の問題も約 50 時間でとくととができるが誤差の集積状況からみて大体 11 次元程度が限度であろうという結論に達した。 